Pakistan Journal of Humanities and Social Sciences

April - June 2018, Volume 6, No. 2, Pages 169 - 187

\title{
The Relationship between Metacognitive Strategies and Self-Efficacy Beliefs: A Review of the Literature
}

\author{
M. Waleed Shehzad ${ }^{1}$, Dr. Mohd Hilmi bin Hamzah ${ }^{2}$, Dr. Rafizah Mohd Rawian ${ }^{3}$ \\ ${ }^{1}$ PhD Scholar | School of Languages, Civilization, and Philosophy | UUM College of Arts \\ and Sciences Universiti Utara Malaysia \\ ${ }^{2}$ Senior Lecturer | School of Languages, Civilisation and Philosophy | UUM College of Arts \\ and Sciences, Universiti Utara Malaysia \\ ${ }^{3}$ Senior Lecturer | School of Languages, Civilisation and Philosophy | UUM College of Arts \\ and Sciences, Universiti Utara Malaysia \\ Email: waleedshehzad@yahoo.com
}

\begin{abstract}
Self-efficacy has been a topic of interest of many researchers since the last couple of decades. Previous literature has revealed that self-efficacy plays a vital role in the usage of metacognitive strategies in language learning. The fundamental aim of this paper is to review those studies which were conducted on the relationship between self-efficacy and metacognitive strategies. Many writers have written reviews on the relationship of selfefficacy with various educational variables. However, there is scarcity of reviews regarding the relationship between self-efficacy beliefs and metacognitive strategies. This review included 21 studies which were reviewed on the basis of following aspects: context of studies, gender, grade level, ethnicity, metacognitive strategy instruction, metacognitive strategies usage ranking, level of self-efficacy, research approaches and pre-test/post-test research designs. Also, several recommendations were presented at the end of the paper for future researchers.
\end{abstract}

Keywords: Metacognitive Strategies, Self-efficacy Beliefs, Systematic Literature Review

\section{Introduction}

\section{A. Metacognitive Strategies}

From the beginning of 1970s, learning strategies have been given special attention by L2 researchers (Anderson, 1991, 2003; Cohen, 1990, 1998; Hosenfeld, 1979; Macaro, 2001; O’Malley and Chamot, 1990; Oxford, 1990, 1993, 2002; Rubin, 1975; Stern, 1975; Wenden, 1991, 2002). Up till now language learning strategies have been classified into many taxonomies. Numerous researchers support the taxonomy of language learning strategies presented by Oxford (1990). He had classified strategies into six types namely, metacognitive 
strategies, cognitive strategies, social strategies, memory strategies, affective strategies, and compensatory strategies in his inventory, i.e. Strategy Inventory for Language Learning (SILL). Similarly, another taxonomy was presented by Anderson (2003), which consisted of seven types of strategies including, metacognitive strategies, cognitive strategies, social strategies, mnemonic or memory associated strategies, self-motivating strategies, affective strategies, and compensatory strategies. On the other hand, there were some researchers whose taxonomies consisted of small amount of strategy types (O'Malley \& Chamot, 1990; Chamot, Barnhardt, El-Dinary, \& Robbins, 1999; Cohen, 1996). For example, O’Malley and Chamot (1990) had classified the strategies into two main kinds, i.e. cognitive and metacognitive strategies. As it is evident from the review of various taxonomies that metacognitive strategies are considered as a vital part of all taxonomies.

Oxford (1990) defined metacognitive strategies as actions done by learners to plan, organize, and assess their learning process. Anderson (2003) believed that metacognitive strategies play a substantial role in the learning process as compared to other strategies for the reason that as soon as the learner knows how to control his/her learning by employing strategies, the process of language learning would take place at a faster rate. Strategic language learners possess metacognitive knowledge regarding their thinking and methods being applied for learning, a sound perception of the requirements of the task at hand, and the capability to plan out the strategies that are according to the task needs and their learning potencies.

\section{B. Self-efficacy Beliefs}

Self-efficacy, which is deemed as the confidence in one's capability to successfully accomplish a task, plays an essential part in the life of a learner (Bandura, 1986). To put it another way, those learners whose level of self-efficacy is high are possibly more productive in their educational career. The idea of self-efficacy was initially offered by Bandura (1997). The definition of self-efficacy as described by Bandura (1997) is as follows: the beliefs of the learners in their abilities to arrange and perform sequences of actions needed to accomplish specific achievements. Furthermore, he was of the view that either a task will be accomplished or not, depends on the individual's self-efficacy level. Those individuals who have higher level of self-efficacy are inspired to put more effort and are determined in accomplishing a task. The concept of self-efficacy is applied to all the four major skills of language, i.e. listening, speaking, reading, and writing. 
It is evident from the research that self-efficacy beliefs of the learners are correlated with the metacognitive learning strategies they use (National Capital Language Resource Center, 2000; Siew \& Wong, 2005; Li \& Wang, 2010; ; Rahimi \& Abedi, 2014; Yailagh, Birgani, Boostani \& Hajiyakhchali, 2013; Javanmard, Hoshmandja \& Ahmadzade, 2012; Nosratinia, Saveiy \& Zaker, 2014; Kargar \& Zamanian, 2014). Those learners whose level of self-efficacy is high employ language learning strategies to perform tasks more often as compared to those students who have moderate or low level of self-efficacy, enthusiastically take part in the process of learning, and therefore accomplish better results (Heidari, Izadi, \& Ahmadian, 2012). However, there is scarcity of the systematic literature reviews regarding self-efficacy and metacognitive strategies. Thus, it is hoped that the current literature review paper fills this literature gap. It is believed that future researchers would be able to get great benefits to identify the extent of work done on the relationship of these two variables.

The basic objective of the current research paper is to summarize the key findings of the past studies on the relationship between self-efficacy and metacognitive strategies. Four main objectives are as follows:

1. To identify the role of certain factors (context/ location of studies, gender, grade level, ethnicity, metacognitive strategy instruction) in determining the relationship between metacognitive strategies and self-efficacy beliefs in the past studies.

2. To identify the ranking of the usage of different metacognitive strategies in the past studies.

3. To identify the level of self-efficacy of participants in the past studies.

4. To identify the research approaches (quantitative, qualitative, mixed-methods, pretest/ post-test design, longitudinal design) employed by past research studies.

\section{Significance of Study}

The current systematic literature review paper would be highly significant for those future researchers who are interested in self-efficacy beliefs and metacognitive strategies due to the reason that this review contains all the relevant studies on the relationship between selfefficacy and metacognitive strategies. Furthermore, it would save a lot of their time in terms of searching for articles as according to researcher's good knowledge it contains all the relevant articles up to current date. 


\section{Methods}

\section{A. Eligibility Criteria and Selection}

A fixed eligibility criteria has been set in this literature review paper. Only those research studies were included which were published in refereed journals. Refereed journal articles were considered due to the fact that they are considered trustworthy as compared to non-refereed journal articles. Initially 31 studies were selected to be included in the current literature review paper. After further inquiry, it was found that 10 studies were non-refereed journal articles. Thus, 21 studies were included in the current paper. ULRICHSWEB was utilized to know whether the research articles are refereed or non-refereed. A comprehensive list of rejected research studies along with journals' names were presented in a Supplementary File 1.

As far as the methodology of the studies is concerned, no restrictions were applied. The present review incorporated all the studies without taking into account the employed in those studies, i.e. Quantitative, Qualitative or mixed-methods research. Similarly, in terms of sample, no particular limitations were applied. Thus, numerous kinds of sample were achieved including, primary, middle, high school, university level students as well as preservice teachers. Also, the authors haven't omitted any studies on the basis of certain factors including, socio-economic status, age, gender etc.

\section{B. Search Strategy}

An organized search of the databases was carried out in order to look for the relevant studies. The particular words or phrases employed while searching include, 'metacognitive strategies', 'metacognitive strategies for learning', 'self-efficacy', 'self-efficacy beliefs', 'learning self-efficacy beliefs', 'relationship between metacognitive strategies and selfefficacy beliefs'. These particular search terms were typed in major databases, i.e. ERIC, Science Direct, Web of Science and Scopus. The final search was done on May 15, 2018. The full search strategy deployed while exploring studies is shown in Figure 1.

\section{Figure 1: Research Approaches}

\section{Databases:}

ERIC, ScienceDirect, Web of Science and Scopus.

\section{Search terms:}

"metacognitive strategies" OR "metacognitive strategies for learning"

AND "self-efficacy" OR "self-efficacy beliefs" OR "learning self-efficacy beliefs

AND "relationship between metacognitive strategies and self-efficacy beliefs" OR

"relationship between metacognitive strategies for learning and reading self-efficacy beliefs"

Limiters: All in English. 
Pakistan Journal of Humanities and Social Sciences, 6(2), 2018

\section{Data Abstraction}

Numerous literature review studies had made use of data abstraction table in order to recapitulate the major essentials of research studies (Honicke \& Broadbent, 2016; Klassen \& Tze, 2014; Van Dinther, Dochy \& Segers, 2011). Thus, after reviewing the aforementioned studies, it was resolved to employ data abstraction table for this article. The main reason behind creating this table was to demonstrate the relevant information in an organized and concise manner. The data gathered after reviewing relevant studies were arranged and incorporated manually. To fill up the data abstraction table, subsequent factors were considered: Location where study was conducted, sample characteristics (number of participants, sex, and average age), names of instruments used to gather data, and major results.

\section{Studies on the Relationship of Metacognitive strategies and Self-efficacy beliefs}

This review includes 21 studies regarding the relationship between self-efficacy and metacognitive strategies. These studies are reviewed based on several factors, including location of studies, gender, grade level, ethnicity, studies involving metacognitive strategy instruction, ranking of metacognitive strategies, level of self-efficacy, research approaches. The researchers reviewed the above mentioned factors because these were the most common factors found in the previous studies involving relationship between self-efficacy and metacognitive strategies. All of these factors are explained in following paragraphs.

\section{A. Context of Studies}

In the current literature review paper, out of 21 studies, 13 were conducted in Iran, five in Turkey, three in Taiwan, two in each, Malaysia and USA, and one in each of the following countries: China, Indonesia, Italy, Egypt and Australia.

Out of 10 studies conducted in Iran, 9 studies have shown that there was a positive significant relationship between self-efficacy beliefs and metacognitive strategies (Zarei \& Gilanian, 2015; Taghinezhad, Dehbozorgi \& Esmaili, 2015; Rahimi \& Abedi, 2014; Yailagh, Birgani, Boostani \& Hajiyakhchali, 2013; Javanmard, Hoshmandja \& Ahmadzade, 2012; Nosratinia, Saveiy \& Zaker, 2014; Zare \& Mobarakeh, 2011; Ahmadian \& Pasand, 2017; Ghavamnia, Kassaian \& Dabaghi, 2011). Conversely, one study indicated that there was no significant relationship between self-efficacy and metacognitive strategies (Bonyadi, Nikou \& Shahbaz, 2012). 
Likewise, two studies were conducted in Taiwan. Both of them have shown that there was a positive and significant relationship between self-efficacy and metacognitive strategies (Shang, 2010; Yang, 1999). Similarly, two studies were conducted in USA. One of them indicated a positive significant relationship between two variables (Jee, 2015). Whereas, the other study (McCrudden, Perkins \& Putney, 2005) didn't check the correlation as it followed pre-test and post-test design. It was found that after metacognitive strategy instruction, selfefficacy of the students had increased.

One study was conducted in each of the following countries: China, Indonesia, Botswana, Italy, Egypt, Turkey and Australia. All of them indicated that there was a positive and significant relationship between self-efficacy and metacognitive strategies ( $\mathrm{Li} \&$ Wang, 2010; Stracke, 2016; Magogwe \& Oliver, 2007; Cera, Mancini \& Antoniette, 2013; Kassem, 2015; Yilmaz, 2010; Purdie \& Oliver, 1999).

It is evident from the above mentioned studies that majority of the research was conducted in Iran with 10 studies. Whereas, Taiwan and USA stand at second place with two studies in each country. Therefore, there is a need to conduct research in other countries to know the outcome between these two variables.

\section{B. Gender}

There were few studies which highlighted the role of gender regarding the relationship between self-efficacy and metacognitive strategies. For instance, Yilmaz (2010) found that both male and female students had used the metacognitive strategies equally. Taghinezhad, Dehbozorgi and Esmaili (2015) also found the similar results, i.e. both male and female students had used the metacognitive strategies on almost equal basis.

However, Bonyadi, Nikou and Shahbaz (2012) had found a different finding as compared to the above mentioned studies. They found that gender had no significant relationship regarding self-efficacy and use of metacognitive strategies.

Ahmadian and Pasand (2017) had revealed that regarding metacognitive strategies, females used more global online reading strategies, while in terms of self-efficacy, males perceived themselves as more self-efficacious in reading online texts.

After reviewing the above mentioned studies, mixed findings were obtained regarding relationship between self-efficacy and metacognitive strategies and also regarding the frequency of usage of metacognitive strategies. Thus, there is a need to conduct more studies on the relationship between self-efficacy and metacognitive strategies by considering the role of gender. 


\section{Grade Level}

Only two studies considered the impact of grade level on self-efficacy and metacognitive strategies. For instance, Magogwe and Oliver (2007) found that out of six strategies, metacognitive strategies were employed most frequently by secondary and tertiary level students. However, primary level students rated them as second most employed strategies.

Javanmard et al. (2012) found that there was no difference regarding general selfefficacy in both Junior and senior high school students. Conversely, in terms of metacognitive strategies, there was difference regarding the usage of metacognitive strategies between junior and senior high school students.

Only two studies have considered the role of grade level in predicting self-efficacy and metacognitive strategies. Thus, future researchers need to consider role of grade level.

\section{Ethnicity}

Out of 21 studies, only two studies considered the role of ethnicity regarding metacognitive strategies and self-efficacy. For instance, Purdie and Oliver (1999) considered three cultural groups in the sample including, Asian, Arabic and European students. It was found that none of the three cultural groups made any difference in the frequency of usage of metacognitive strategies.

On the other hand, Jee (2015) divided his sample into two groups, i.e. heritage and non-heritage students. Heritage students were considered as those whose parents were from Korea and non-heritage were those whose parents did not belong to Korea. With regard to metacognitive strategies, it was revealed that non-heritage students employed metacognitive strategies more frequently as compared to heritage students. Whereas, in terms of selfefficacy level of self-efficacy of heritage students $(M=3.35)$ was higher as compared to nonheritage students $(\mathrm{M}=2.83)$.

It is clear that there is scarcity of ethnic element in the studies on the relationship of self-efficacy and metacognitive strategies. Therefore, future research needs to focus on ethnic element.

\section{E. Metacognitive Strategy Instruction}

Out of 21 studies that were reviewed in this paper, only one of them involved metacognitive strategy instruction. For instance, Taghinezhad et al. (2015) conducted a study in Iran on 90 Iranian EFL students studying in English learning institute. It was an experimental study in which they tried to determine the impact metacognitive strategy 
instruction on the self-efficacy beliefs of the students. The sample was divided into experimental and control group. Experimental group were taught metacognitive reading strategies. Results revealed that experimental group had outperformed the control group.

There is scarcity of research regarding metacognitive strategy instruction. Thus, it is recommended to future researchers to consider metacognitive strategy instruction in the studies on the relationship between self-efficacy and metacognitive strategies.

\section{F. Ranking of Metacognitive Strategies Usage}

Out of several strategies, 12 studies indicated the ranking of metacognitive strategies usage. 9 studies had revealed that metacognitive strategies were employed most frequently out of several strategies (Li \& Wang, 2010; Zare \& Mobarakeh, 2011; Shang, 2010; Bonyadi et al. 2012; Ahmadian \& Pasand, 2017; Purdie \& Oliver, 1999; Jee, 2015; Stracke, 2016; Magogwe \& Oliver, 2007). However, three studies indicated that metacognitive strategies were reported as second most frequent employed strategies (Yilmaz, 2010; Kassem, 2015; Ghavamnia, Kassaian \& Dabaghi, 2011).

\section{G. Level of Self-efficacy}

Nine studies had determined the level of self-efficacy of the students. Li and Wang (2010) indicated that the level of reading self-efficacy was above average with the mean of 4.71 out of 7. Rahimi and Abedi (2014) found that the level of self-efficacy was found to be average. Zare and Mobarakeh (2011) found that students had appropriate level of self-efficacy with mean score of 47 out of 70 .

Taghinezhad et al., (2015) found the similar findings regarding level of self-efficacy. The results revealed that after metacognitive strategy instruction, the level of self-efficacy of the experimental group elevated as compared to the control group.

Jee (2015) found the level of two separate groups, i.e. heritage and non-heritage students. It was found that level of self-efficacy of heritage students $(M=3.35)$ was higher as compared to non-heritage students $(\mathrm{M}=2.83)$. Also, Yang (1999) in his study found that the level of English self-efficacy of the students was high.

\section{H. Research Approaches}

After reviewing 21 studies, it was revealed that 18 studies employed quantitative research approach. Whereas, three studies employed Mixed-methods research approach. Interestingly, it was found that not even a single study employed purely qualitative research approach as shown in Figure 1. 
Figure 2: Research Approaches

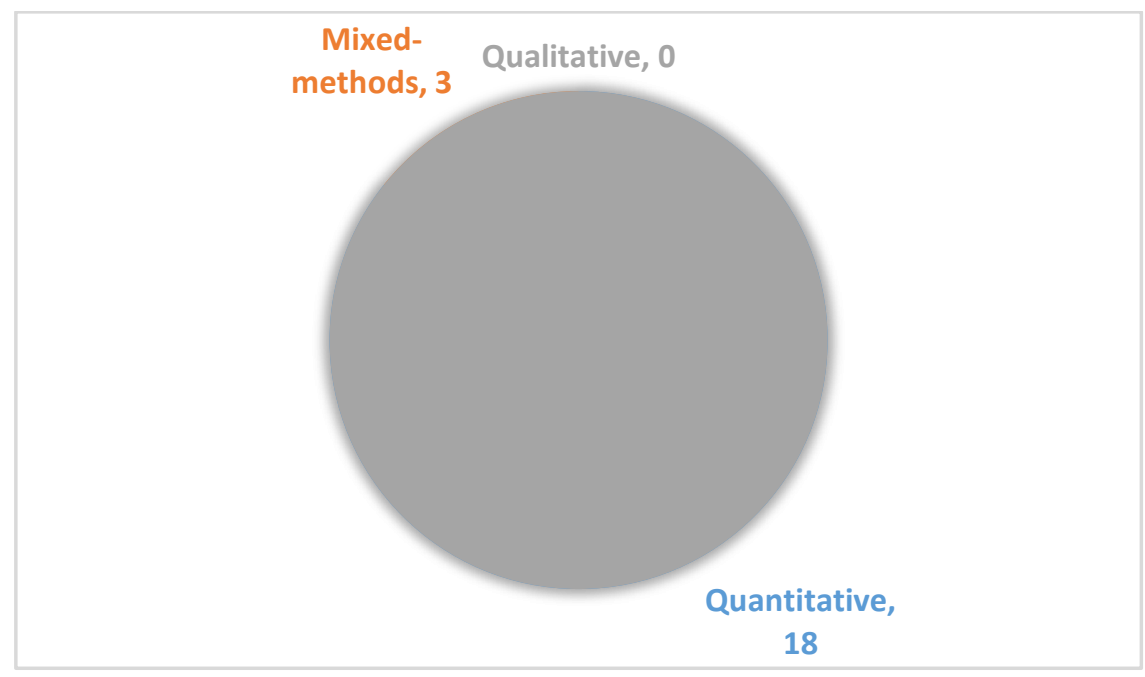

\section{J. Pre-test and Post-test Research Designs}

After reviewing 21 studies, it was revealed that pre-test and post-test research design was employed by only two studies. Taghinezhad et al. (2015) conducted a study to know the impact of metacognitive strategy instruction on self-efficacy beliefs and reading attainment. The sample consisted of 90 Iranian EFL students in English learning institute. The results indicated that the group which was exposed to metacognitive strategy instruction, i.e. experimental group had outclassed control group. Both the aforementioned studies are quite similar in many aspects including, sample size, country, and research design.

Also, McCrudden et al. (2005) used pre-test and post-test design in their study. The sample comprised of $234^{\text {th }}$ grade students in USA. Reading strategy instruction was exposed to all the 23 students. This study is different from aforementioned studies in respect that it hasn't divided its sample into experimental and control groups. The findings revealed that self-efficacy increased from pre-instruction $(\mathrm{M}=18.87, \mathrm{SD}=2.03)$ to post-instruction $(\mathrm{M}=$ $20.78, \mathrm{SD}=2.83)$.

\section{Conclusion}

This review of the literature involving two variables, i.e. self-efficacy and metacognitive strategies contained 21 empirical studies. Important findings were gathered. Regarding the location of research done on the aforementioned variables, most of the research was conducted in Iran with 10 studies followed by Taiwan and USA with 2 studies in each 
country. However, in other countries, scarce amount of research was done regarding selfefficacy and metacognitive reading strategies. Therefore, there is a need to conduct more research in other countries as well.

Also, role of gender was neglected. Only four studies considered the role played by gender in determining self-efficacy and metacognitive strategies usage. Similarly, role of ethnicity was neglected. It was found that only two studies had taken ethnicity into account. Regarding the sample of reviewed studies, it was found that only one study, i.e. (Wong, 2005) was conducted involving teachers as a sample. Otherwise, 20 studies were conducted on students. Thus, clearly, there is a need to conduct more studies on teachers. A crucial finding regarding metacognitive strategies was revealed. Majority of the studies indicated that out of several strategies, metacognitive strategies were employed most frequently by the students.

Regarding research methodology of reviewed studies, it was found that majority of the studies were quantitative in nature, i.e. 18, whereas, only three studies had employed mixed-methods research design. Interestingly, not even a single study was conducted by employing qualitative research design. Thus, there is a sheer need to conduct more qualitative studies. Similarly, two studies had employed pre-test/post-test design. Thus, more research needs to be done by using this research design. Furthermore, an interesting finding was revealed that not only a single study was longitudinal in nature. 
Pakistan Journal of Humanities and Social Sciences, 6(2), 2018

\section{References}

References marked with an asterisk indicate studies included in the meta-analysis

*Ahmadian, M., \& Pasand, P. G. (2017). EFL Learners' Use of Online Metacognitive Reading Strategies and its Relation to their Self-Efficacy in Reading. The Reading Matrix: An International Online Journal, 17(2).

Anderson, N. J. (1991). Individual differences in strategy use in second language reading and testing. Modern Language Journal, 75, 460-472.

Anderson, N. J. (2003). Metacognitive reading strategies increase L2 performance. The Language Teacher, 27, 20-22.

Bandura, A. (1986). The explanatory and predictive scope of self-efficacy theory. Journal of social and clinical psychology, 4(3), 359-373.

Bandura, A. (1997). Self-efficacy: The exercise of control. Macmillan.

Bialystok, E. (1990). Communication strategies: A psychological analysis of secondlanguage use. B. Blackwell.

*Bonyadi, A., Nikou, F. R., \& Shahbaz, S. (2012). The relationship between EFL learners' self-efficacy beliefs and their language learning strategy use. English language teaching, 5(8), 113.

*Cera, R., Mancini, M., \& Antonietti, A. (2013). Relationships between metacognition, selfefficacy and self-regulation in learning. Journal of Educational, Cultural and Psychological Studies (ECPS Journal), 4(7), 115-141.

Chamot, A. U., Barnhardt, S., El-Dinary, P. B., and Robbins, J. (1999). The learning strategies handbook. New York: Longman.

Cohen, A. D. (1990). Language learning: Insights for learners, teachers, and researchers. New York: Newbury House.

Cohen, A. D. (1996). Second language learning and use strategies: Clarifying the issues. CARLA Working Paper Series \#3. Minneapolis, MN: The University of Minnesota.

Cohen, A.D. (1998). Strategies in learning and using a second language. Harlow: Longman.

*Ghavamnia, M., Kassaian, Z., \& Dabaghi, A. (2011). The Relationship between Language Learning Strategies, Language Learning Beliefs, Motivation, and Proficiency: A Study of EFL Learners in Iran. Journal of Language Teaching \& Research, 2(5).

Heidari, F., Izadi, M., \& Ahmadian, M. (2012). The relationship between Iranian EFL learners' self-efficacy beliefs and use of vocabulary learning strategies. English language teaching, 5(2), 174-182. 
Hosenfeld, C. (1979). A learning-teaching view of second language instruction. Foreign Language Annals, 12, 51-57.

*Javanmard, A., Hoshmandja, M., \& Ahmadzade, L. (2012). Investigating the relationship between self-efficacy, Cognitive and metacognitive strategies, and academic selfhandicapping with academic achievement in male high school students in the Tribes of Fars Province. Journal of Iife Science and Biomedicine, 3(1), 27-34.

*Jee, M. J. (2015). Language learners' strategy use and self-efficacy: Korean heritage learners versus non-heritage learners.

*Kassem, H. M. (2015). The Relationship between Listening Strategies Used by Egyptian EFL College Sophomores and Their Listening Comprehension and SelfEfficacy. English Language Teaching, 8(2), 153-169.

*Li, Y., \& Wang, C. (2010). An empirical study of reading self-efficacy and the use of reading strategies in the Chinese EFL context. Asian EFL Journal, 12(2), 144-162.

Macaro, E. (2001). Learning strategies in foreign and second language classrooms. London: Continuum.

*Magogwe, J. M., \& Oliver, R. (2007). The relationship between language learning strategies, proficiency, age and self-efficacy beliefs: A study of language learners in Botswana. System, 35(3), 338-352.

*McCrudden, M. T., Perkins, P. G., \& Putney, L. G. (2005). Self-efficacy and interest in the use of reading strategies. Journal of Research in Childhood Education, 20(2), 119131.

National Capital Language Resource Center. (2000). High school foreign language students' perceptions of langue learning strategies use and self-efficacy. Washington, D. C.: U. S. Department of Education.

*Nosratinia, M., Saveiy, M., \& Zaker, A. (2014). EFL learners' self-efficacy, metacognitive awareness, and use of language learning strategies: how are they associated? Theory and Practice in Language Studies, 4(5), 1080.

O'Malley, J. M., and Chamot, A. U. (1990). Learning strategies in second language acquisition. New York: Cambridge University Press.

Oxford, R. (2002). Language learning strategies. In R. Carter and D. Nunan (Eds.), The Cambridge guide to teaching English to speakers of other languages (pp. 166-172). Cambridge: Cambridge University Press. 
Pakistan Journal of Humanities and Social Sciences, 6(2), 2018

Oxford, R. L. (1990). Language learning strategies: What every teacher should know. New York: Newbury House Publishers.

Oxford, R. L. (2003). Language learning styles and strategies: An Overview. Oxford: GALA.

Oxford, R.L. (1993). Research on second language learning strategies. Annual Review of Applied Linguistics, 13, 175-187.

Oxford, R.L. (1996).Language learning strategies around the world: Cross-cultural perspectives. Manoa: University of Hawaii Press.

Pressley, M., and McCormick, C.B. (1995). Advanced educational psychology for educators, researchers, and policymakers. New York: HarperCollins.

*Purdie, N., \& Oliver, R. (1999). Language learning strategies used by bilingual school-aged children. System, 27(3), 375-388.

*Rahimi, M., \& Abedi, S. (2014). The relationship between listening self-efficacy and metacognitive awareness of listening strategies. Procedia-Social and Behavioral Sciences, 98, 1454-1460.

Rubin, J. (1975). What the "good language learner" can teach us? TESOL Quarterly, 9, 4151.

*Shang, H. F. (2010). Reading strategy use, self-efficacy and EFL reading comprehension. Asian EFL Journal, 12(2), 18-42.

Stern, H. H. (1975). What can we learn from the good language learner? Canadian Modern Language Review, 31, 304-318.

*Stracke, E. (2016). Language learning strategies of Indonesian primary school students: In relation to self-efficacy beliefs. System, 60, 1-10.

*Taghinezhad, A., Dehbozorgi, R., \& Esmaili, N. (2015). The influence of teaching metacognitive reading strategies on the reading self-efficacy beliefs of Iranian EFL learners: An experimental study. Modern Journal of Language Teaching Methods, 5(4), 728.

Wenden, A. (1991). Learner strategies for learner autonomy: Planning and implementing learner training for language learners. New York: Prentice Hall.

Wenden, A. L. (2002). Learner development in language learning. Applied Linguistics, 23, $32-55$.

*Yailagh, M. S., Birgani, S. A., Boostani, F., \& Hajiyakhchali, A. (2013). The relationship of self-efficacy and achievement goals with metacognition in female high school students in Iran. Procedia-Social and Behavioral Sciences, 84, 117-119. 
*Yang, N. D. (1999). The relationship between EFL learners' beliefs and learning strategy use. System, 27(4), 515-535.

*Yllmaz, C. (2010). The relationship between language learning strategies, gender, proficiency and self-efficacy beliefs: A study of ELT learners in Turkey. ProcediaSocial and Behavioral Sciences, 2(2), 682-687.

*Zare, M., \& Mobarakeh, S. D. (2011). The relationship between self-efficacy and use of reading strategies: The case of Iranian senior high school students. Studies in Literature and Language, 3(3), 98.

*Zarei, A. A., \& Gilanian, M. (2015). Self-efficacy as a function of language learning strategy use. British Journal of Education, Society \& Behavioural Science, 9(3), 223-235.

Table 1: Summarized Table of Studies Related to the Relationship between Selfefficacy and Metacognitive Strategies

\begin{tabular}{|c|c|c|c|c|c|}
\hline Author & Title of Article & $\begin{array}{l}\text { Participants and } \\
\text { Location of Study }\end{array}$ & $\begin{array}{c}\text { Study design, } \\
\text { Predictor measure and } \\
\text { Outcome measure }\end{array}$ & Findings & 离 \\
\hline $\begin{array}{l}\text { Li and } \\
\text { Wang } \\
(2010)\end{array}$ & $\begin{array}{c}\text { An Empirical } \\
\text { Study of Reading } \\
\text { Self-efficacy and } \\
\text { the Use of } \\
\text { Reading } \\
\text { Strategies in the } \\
\text { Chinese EFL } \\
\text { Context }\end{array}$ & $\begin{array}{c}139 \text { ( } 87 \% \text { F \& } 13 \% \\
\text { M) Chinese first } \\
\text { semester University } \\
\text { students majoring in } \\
\text { English. } \\
\text { *Age: } 18 \text { to } 22 \text { (Avg. } \\
\text { age }=20.34) \\
\text { *Location: China }\end{array}$ & $\begin{array}{l}\text { *QUAN } \\
\text { S.E measure: The } \\
\text { reading self-efficacy } \\
\text { questionnaire (Wang, } \\
\text { 2007). } \\
\text { Metacognitive strategy } \\
\text { measure: The use of } \\
\text { reading strategies } \\
\text { questionnaire (O’Malley } \\
\text { \& Chamot, 1990). }\end{array}$ & $\begin{array}{l}\text { 1. There is a positive significant relationship } \\
\text { between self-efficacy beliefs and the use of } \\
\text { reading strategies including metacognitive } \\
\text { reading strategies. } \\
\text { 2. More reading strategies have been used by } \\
\text { the students whose self-efficacy level is high } \\
\text { as compared to low self-efficacious students. } \\
\text { 3. Metacognitive reading strategies were used } \\
\text { most frequently out of three strategies. } \\
\text { 4. The level of self-efficacy was above average } \\
\text { with the mean of } 4.71 \text { out of } 7 \text {. }\end{array}$ & \\
\hline $\begin{array}{l}\text { Y1lmaz } \\
(2010)\end{array}$ & $\begin{array}{l}\text { The relationship } \\
\text { between } \\
\text { language } \\
\text { learning } \\
\text { strategies, } \\
\text { gender, } \\
\text { proficiency and } \\
\text { self-efficacy } \\
\text { beliefs: a study } \\
\text { of ELT learners } \\
\text { in Turkey }\end{array}$ & $\begin{array}{c}140 \text { (117 F \& } 23 \mathrm{M}) \\
\text { university students } \\
\text { majoring in English } \\
\text { *Location: Turkey }\end{array}$ & $\begin{array}{c}\text { *QUAN } \\
\text { S.E measure: Unknown } \\
\text { Metacognitive strategy } \\
\text { measure: Strategy } \\
\text { Inventory for Language } \\
\text { Learning (SILL) } \\
\text { (Oxford, 1990). }\end{array}$ & $\begin{array}{l}\text { 1. Metacognitive strategies were second most } \\
\text { frequently used strategies out of six strategies. } \\
\text { 2. More proficient students have used more } \\
\text { metacognitive strategies and vice versa. } \\
\text { 3. Both male and female students have used } \\
\text { the metacognitive strategies equally. } \\
\text { 4. Significant positive relationship between the } \\
\text { use of metacognitive strategies and self- } \\
\text { efficacy beliefs. }\end{array}$ & $\checkmark$ \\
\hline $\begin{array}{c}\text { Zarei } \\
\text { and } \\
\text { Gilanian } \\
(2015)\end{array}$ & $\begin{array}{l}\text { Self-efficacy as a } \\
\text { Function of } \\
\text { Language } \\
\text { Learning } \\
\text { Strategy Use }\end{array}$ & $\begin{array}{l}147 \text { male and female } \\
\text { Iranian university } \\
\text { students majoring in } \\
\text { English } \\
\text { *Location: Iran }\end{array}$ & $\begin{array}{c}\text { *QUAN } \\
\text { S.E measure: } \\
\text { 1. Sherer's general self- } \\
\text { efficacy (SGSES). } \\
\text { 2. Academic self- } \\
\text { efficacy scale (Chemers, } \\
\text { Hu \& Garcia, 2001). } \\
\text { 3. Bandura's self- } \\
\text { efficacy for self- } \\
\text { regulated learning scale. } \\
\text { Metacognitive strategy } \\
\text { measure: a Strategy }\end{array}$ & $\begin{array}{l}\text { Metacognitive strategies were positively } \\
\text { correlated with academic self-efficacy. } \\
\text { However, metacognitive strategies were not } \\
\text { correlated with general self-efficacy and self- } \\
\text { regulated self-efficacy. }\end{array}$ & $\checkmark$ \\
\hline
\end{tabular}




\begin{tabular}{|c|c|c|c|c|c|}
\hline & & & $\begin{array}{c}\text { Inventory for Language } \\
\text { Learning (Oxford, } \\
1990) .\end{array}$ & & \\
\hline $\begin{array}{l}\text { Taghine } \\
\text { zhad, } \\
\text { Dehbozo } \\
\text { rgi and } \\
\text { Esmaili } \\
(2015)\end{array}$ & $\begin{array}{l}\text { The influence of } \\
\text { teaching } \\
\text { metacognitive } \\
\text { reading strategies } \\
\text { on the reading } \\
\text { self-efficacy } \\
\text { beliefs of Iranian } \\
\text { EFL learners: an } \\
\text { experimental } \\
\text { study }\end{array}$ & $\begin{array}{l}90(49 \mathrm{~F} \& 40 \mathrm{M}) \\
\text { Iranian EFL students } \\
\text { studying in English } \\
\text { learning institute. } \\
\text { The students were } \\
\text { divided into } \\
\text { experimental and } \\
\text { control groups. } \\
\text { *Age: } 18 \text { to } 30 . \\
\text { *Location: Iran }\end{array}$ & $\begin{array}{c}\text { *QUAN (*pre \& post- } \\
\text { test design) } \\
\text { S.E measure: Reading } \\
\text { Self-efficacy Beliefs } \\
\text { Questionnaire (RSEQ) } \\
\text { (developed by } \\
\text { researcher). } \\
\text { Metacognitive strategy } \\
\text { measure: } \\
\text { Metacognitive strategy } \\
\text { instruction. }\end{array}$ & $\begin{array}{l}\text { 1. Self-efficacy beliefs are positively } \\
\text { correlated with the teaching of metacognitive } \\
\text { reading strategies. } \\
\text { 2. Experimental group had outperformed the } \\
\text { control group both in reading achievement and } \\
\text { self-efficacy. } \\
\text { 3. Both male and female students have used } \\
\text { the metacognitive strategies on almost equal } \\
\text { basis. }\end{array}$ & $\checkmark$ \\
\hline $\begin{array}{l}\text { Rahimi } \\
\text { and } \\
\text { Abedi } \\
(2014)\end{array}$ & $\begin{array}{l}\text { The Relationship } \\
\text { between } \\
\text { Listening Self- } \\
\text { efficacy and } \\
\text { Metacognitive } \\
\text { Awareness of } \\
\text { Listening } \\
\text { Strategies }\end{array}$ & $\begin{array}{l}371 \text { High-school } \\
\text { students } \\
\text { *Location: Iran }\end{array}$ & $\begin{array}{c}\text { *QUAN } \\
\text { S.E measure: English } \\
\text { Listening Self-efficacy } \\
\text { Questionnaire (ELSEQ) } \\
\text { (developed by } \\
\text { researcher). } \\
\text { Metacognitive strategy } \\
\text { measure: } \\
\text { Metacognitive } \\
\text { Awareness Listening } \\
\text { Questionnaire (MALQ) } \\
\text { (Vandergrift et al., } \\
\text { 2006). }\end{array}$ & $\begin{array}{l}\text { 1. The level of listening self-efficacy was } \\
\text { found to be average. } \\
\text { 2. The level of metacognitive awareness of } \\
\text { listening strategies was average. } \\
\text { 3. Listening self-efficacy is positively and } \\
\text { significantly related with metacognitive } \\
\text { awareness of listening strategies. }\end{array}$ & $\checkmark$ \\
\hline $\begin{array}{l}\text { Yailagh, } \\
\text { Birgani, } \\
\text { Boostani } \\
\text { and } \\
\text { Hajiyakh } \\
\text { chali } \\
\text { (2013) }\end{array}$ & $\begin{array}{l}\text { The Relationship } \\
\text { Of Self-efficacy } \\
\text { And } \\
\text { Achievement } \\
\text { Goals With } \\
\text { Metacognition In } \\
\text { Female High } \\
\text { School Students } \\
\text { In Iran }\end{array}$ & $\begin{array}{l}230 \text { female high } \\
\text { school students } \\
\text { *Location: Iran }\end{array}$ & $\begin{array}{c}\text { *QUAN } \\
\text { S.E measure: MSLQ } \\
\text { (Pintrich \& colleagues, } \\
\text { 1993). } \\
\text { Metacognitive strategy } \\
\text { measure: } \\
\text { Metacognition } \\
\text { Awareness Inventory } \\
\text { (Schraw \& Dennison, } \\
\text { 1994). }\end{array}$ & $\begin{array}{l}\text { Self-efficacy beliefs and metacognition are } \\
\text { positively correlated to each other. }\end{array}$ & $\checkmark$ \\
\hline $\begin{array}{l}\text { Javanma } \\
\text { rd, } \\
\text { Hoshma } \\
\text { ndja and } \\
\text { Ahmadz } \\
\text { ade } \\
(2012)\end{array}$ & $\begin{array}{l}\text { Investigating the } \\
\text { Relationship } \\
\text { between Self- } \\
\text { Efficacy, } \\
\text { Cognitive and } \\
\text { Metacognitive } \\
\text { Strategies, and } \\
\text { Academic Self- } \\
\text { Handicapping } \\
\text { with Academic } \\
\text { Achievement in } \\
\text { Male High } \\
\text { School Students } \\
\text { in the Tribes of } \\
\text { Fars Province }\end{array}$ & $\begin{array}{l}322 \text { male high school } \\
\text { students } \\
\text { *Location: Iran }\end{array}$ & $\begin{array}{c}\text { *QUAN } \\
\text { S.E measure: } \\
\text { Generalized Self- } \\
\text { efficacy Scale } \\
\text { (Schwarzer \& } \\
\text { Jerusalem, 1995). } \\
\text { Metacognitive strategy } \\
\text { measure: Cognitive and } \\
\text { metacognitive strategies } \\
\text { scale. }\end{array}$ & $\begin{array}{l}\text { 1. Metacognitive strategies and self-efficacy } \\
\text { have a significant relationship with academic } \\
\text { achievement. } \\
\text { 2. There was no difference regarding general } \\
\text { self-efficacy in both Junior and senior high } \\
\text { school students. } \\
\text { 3. There was difference regarding the usage of } \\
\text { metacognitive strategies between junior and } \\
\text { senior high school students. }\end{array}$ & $\checkmark$ \\
\hline $\begin{array}{l}\text { Nosratin } \\
\text { ia, } \\
\text { Saveiy } \\
\text { and } \\
\text { Zaker } \\
(2014)\end{array}$ & $\begin{array}{l}\text { EFL Learners' } \\
\text { Self-efficacy, } \\
\text { Metacognitive } \\
\text { Awareness, and } \\
\text { Use of Language } \\
\text { Learning } \\
\text { Strategies: How } \\
\text { Are They } \\
\text { Associated? }\end{array}$ & $\begin{array}{c}143 \text { (109 F \& } 34 \mathrm{M}) \\
\text { EFL university } \\
\text { students majoring in } \\
\text { English literature. } \\
\text { *Location: Iran }\end{array}$ & $\begin{array}{c}\text { *QUAN } \\
\text { S.E measure: General } \\
\text { Self-Efficacy Scale } \\
\text { (Schwarzer \& } \\
\text { Jerusalem, 1996). } \\
\text { Metacognitive strategy } \\
\text { measure: The } \\
\text { Metacognitive } \\
\text { Awareness Inventory } \\
\text { (Schraw \& Dennison, } \\
\text { 1994). }\end{array}$ & $\begin{array}{l}\text { 1. Positive significant relationship between } \\
\text { metacognitive awareness and self-efficacy, } \\
\text { 2. Positive significant relationship between } \\
\text { self-efficacy and metacognitive language } \\
\text { strategies usage } \\
\text { 3. Positive significant relationship between } \\
\text { metacognitive awareness and metacognitive } \\
\text { strategies usage. }\end{array}$ & $\checkmark$ \\
\hline
\end{tabular}




\begin{tabular}{|c|c|c|c|c|c|}
\hline $\begin{array}{c}\text { Zare and } \\
\text { Mobarak } \\
\text { eh } \\
(2011)\end{array}$ & $\begin{array}{l}\text { The Relationship } \\
\text { Between Self- } \\
\text { Efficacy and Use } \\
\text { of Reading } \\
\text { Strategies: The } \\
\text { Case of Iranian } \\
\text { Senior High } \\
\text { School Students }\end{array}$ & $\begin{array}{c}45 \text { grade } 3 \text { students. } \\
\text { *Age: } 17 \text { to } 19 . \\
\text { *Location: Iran }\end{array}$ & $\begin{array}{c}\text { *QUAN } \\
\text { S.E measure: Reading } \\
\text { Self-Efficacy } \\
\text { Questionnaire (Wang, } \\
\text { 2007; Li \& Wang, } \\
\text { 2010). } \\
\text { Metacognitive strategy } \\
\text { measure: The use of } \\
\text { reading strategies } \\
\text { questionnaire (Li \& } \\
\text { Wang, 2010). }\end{array}$ & $\begin{array}{l}\text { 1. Students had appropriate level of self- } \\
\text { efficacy with mean score of } 47 \text { out of } 70 \text {. } \\
\text { 2. Metacognitive reading strategies were the } \\
\text { most frequently used strategies out of three } \\
\text { strategies. } \\
\text { 3. Self-efficacy beliefs are positively and } \\
\text { significantly correlated to the use of reading } \\
\text { strategies including metacognitive strategies. }\end{array}$ & $\checkmark$ \\
\hline $\begin{array}{l}\text { Cera, } \\
\text { Mancini } \\
\text { and } \\
\text { Antoniet } \\
\text { te (2013) }\end{array}$ & $\begin{array}{l}\text { Relationships } \\
\text { between } \\
\text { metacognition, } \\
\text { self-efficacy and } \\
\text { self-regulation in } \\
\text { learning }\end{array}$ & $\begin{array}{l}130 \text { high school } \\
\text { students } \\
\text { *Age: } 17 \text { to } 20 . \\
\text { *Location: Italy }\end{array}$ & $\begin{array}{c}\text { *QUAN } \\
\text { S.E measure: Adaptive } \\
\text { Self-efficacy Scale } \\
\text { (Sibilia, Schwarzer, \& } \\
\text { Jerusalem, 1995). } \\
\text { Metacognitive strategy } \\
\text { measure: } \\
\text { Metacognitive } \\
\text { Awareness Inventory } \\
\text { (Schraw \& Dennis, } \\
\text { 1994). } \\
\end{array}$ & $\begin{array}{l}\text { Positive correlation between metacognition } \\
\text { and self-efficacy beliefs. }\end{array}$ & $\checkmark$ \\
\hline $\begin{array}{l}\text { Shang } \\
(2010)\end{array}$ & $\begin{array}{l}\text { Reading Strategy } \\
\text { Use, Self- } \\
\text { Efficacy and } \\
\text { EFL Reading } \\
\text { Comprehension }\end{array}$ & $\begin{array}{c}53(36 \mathrm{~F} \& 17 \mathrm{M}) \\
\text { university students } \\
\text { majoring in English. } \\
\text { *Age: } 18 \text { to } 23 \\
\text { (*avg. age=18.6). } \\
\text { *Location: Taiwan }\end{array}$ & $\begin{array}{l}\text { *Mixed-methods } \\
\text { (Questionnaires \& } \\
\text { interviews) } \\
\text { S.E measure: Self- } \\
\text { efficacy questionnaire } \\
\text { was developed by } \\
\text { author based on } \\
\text { questionnaires of Wong } \\
\text { (2005) and Pintrich et } \\
\text { al. (1991). } \\
\text { Metacognitive strategy } \\
\text { measure: SILL } \\
\text { (Oxford, 1990). }\end{array}$ & $\begin{array}{l}\text { 1. Out of three strategies, metacognitive } \\
\text { strategies have been used most frequently. } \\
\text { 2. Positive significant relationship between } \\
\text { self-efficacy and metacognitive reading } \\
\text { strategies use. } \\
\text { 3. Metacognitive strategies were not } \\
\text { significantly correlated to reading } \\
\text { comprehension. } \\
\text { 4. Interviews' results have found the particular } \\
\text { conditions the students use specific strategies. }\end{array}$ & $\checkmark$ \\
\hline $\begin{array}{l}\text { Bonyadi, } \\
\text { Nikou } \\
\text { and } \\
\text { Shahbaz } \\
(2012)\end{array}$ & $\begin{array}{l}\text { The Relationship } \\
\text { between EFL } \\
\text { Learners' Self- } \\
\text { efficacy Beliefs } \\
\text { and Their } \\
\text { Language } \\
\text { Learning } \\
\text { Strategy Use }\end{array}$ & $\begin{array}{l}210 \text { university } \\
\text { students selected } \\
\text { from } 3 \text { universities. } \\
\text { *Age: } 19 \text { to } 22 \text {. } \\
\text { *Location: Iran }\end{array}$ & $\begin{array}{c}\text { *QUAN } \\
\text { S.E measure: General } \\
\text { Self-efficacy Scale } \\
\text { (Nezami, Schwarzer, \& } \\
\text { Jerusalem, 1996). } \\
\text { Metacognitive strategy } \\
\text { measure: SILL } \\
\text { (Oxford, 1990). }\end{array}$ & $\begin{array}{l}\text { 1. Out of six strategies, metacognitive } \\
\text { strategies were used most frequently. } \\
\text { 2. Gender had made no significant influence in } \\
\text { predicting self-efficacy and use of } \\
\text { metacognitive strategies. } \\
\text { 3. No significant relationship between self- } \\
\text { efficacy beliefs and metacognitive strategies. } \\
\text { 4. Those students who had studied English for } \\
\text { more than } 3 \text { years had higher level of self- } \\
\text { efficacy than those who studied English for } \\
\text { less than } 3 \text { years. }\end{array}$ & $x$ \\
\hline $\begin{array}{l}\text { Ahmadia } \\
\mathrm{n} \text { and } \\
\text { Pasand } \\
(2017)\end{array}$ & $\begin{array}{l}\text { EFL Learners' } \\
\text { Use of Online } \\
\text { Metacognitive } \\
\text { Reading } \\
\text { Strategies and its } \\
\text { Relation to their } \\
\text { Self-Efficacy in } \\
\quad \text { Reading }\end{array}$ & $\begin{array}{c}63 \text { (40 F \& } 23 \mathrm{M}) \\
\text { university students } \\
\text { majoring in English. } \\
\text { *Age } 19 \text { to } 23 \\
\text { *Location: Iran }\end{array}$ & $\begin{array}{c}\text { *QUAN } \\
\text { S.E measure: Reading } \\
\text { Self-efficacy } \\
\text { questionnaire (Zare \& } \\
\text { Mobarakeh, 2011). } \\
\text { Metacognitive strategy } \\
\text { measure: Online } \\
\text { Survey of Reading } \\
\text { Strategies (Anderson, } \\
\text { 2003). }\end{array}$ & $\begin{array}{l}\text { 1. Problem-solving online metacognitive } \\
\text { reading strategies are most frequently used by } \\
\text { the learners. } \\
\text { 2. Significant positive relationship between the } \\
\text { learners' perceived use of metacognitive } \\
\text { online reading strategies and their self-efficacy } \\
\text { in reading comprehension. } \\
\text { 3. Females use more global online reading } \\
\text { strategies, while males perceive themselves as } \\
\text { more self-efficacious in reading online texts. } \\
\text { 4. Learners also used some other } \\
\text { metacognitive strategies while reading online. }\end{array}$ & \\
\hline $\begin{array}{l}\text { Kassem } \\
(2015)\end{array}$ & $\begin{array}{l}\text { The Relationship } \\
\text { between } \\
\text { Listening } \\
\text { Strategies Used } \\
\text { by Egyptian EFL } \\
\text { College } \\
\text { Sophomores and } \\
\text { Their Listening } \\
\text { Comprehension }\end{array}$ & $\begin{array}{l}84 \text { male and female } \\
\text { EFL college } \\
\text { sophomores } \\
\text { majoring in English. } \\
\text { *Avg. age }=20 . \\
\text { *Location: Egypt }\end{array}$ & $\begin{array}{c}\text { *QUAN } \\
\text { S.E measure: Listening } \\
\text { Self-efficacy } \\
\text { Questionnaire } \\
\text { (developed by } \\
\text { researcher). } \\
\text { Metacognitive strategy } \\
\text { measure: Listening } \\
\text { Strategy Questionnaire, }\end{array}$ & $\begin{array}{l}\text { 1. Cognitive strategies were used more often } \\
\text { by participants, followed by metacognitive and } \\
\text { socio-affective strategies. } \\
\text { 2. Listening strategies correlated significantly } \\
\text { with both listening comprehension and self- } \\
\text { efficacy. } \\
\text { 3. Participants with high frequent overall } \\
\text { strategy use, cognitive strategies and } \\
\text { metacognitive strategies outperformed their }\end{array}$ & \\
\hline
\end{tabular}


Pakistan Journal of Humanities and Social Sciences, 6(2), 2018

\begin{tabular}{|c|c|c|c|c|c|}
\hline & and Self-Efficacy & & $\begin{array}{l}\text { developed by researcher } \\
\text { based on several } \\
\text { questionnaires. }\end{array}$ & $\begin{array}{l}\text { counterparts with low frequency strategy use } \\
\text { in both listening comprehension and self- } \\
\text { efficacy. }\end{array}$ & \\
\hline $\begin{array}{l}\text { Ghavam } \\
\text { nia, } \\
\text { Kassaian } \\
\text { and } \\
\text { Dabaghi } \\
\text { (2011) }\end{array}$ & $\begin{array}{l}\text { The Relationship } \\
\text { between } \\
\text { Language } \\
\text { Learning } \\
\text { Strategies, } \\
\text { Language } \\
\text { Learning Beliefs, } \\
\text { Motivation, and } \\
\text { Proficiency: A } \\
\text { Study of EFL } \\
\text { Learners in Iran }\end{array}$ & $\begin{array}{l}80 \text { university } \\
\text { undergraduate } \\
\text { female students } \\
\text { majoring in Applied } \\
\text { Linguistics (F) } \\
\text { *Age: Early twenties } \\
\text { *Location: Iran }\end{array}$ & $\begin{array}{c}\text { *QUAN } \\
\text { S.E measure: The } \\
\text { Beliefs about Language } \\
\text { Learning Inventory } \\
\text { (BALLI) (Horwitz, } \\
\text { 1988). } \\
\text { Metacognitive } \\
\text { strategies measure: } \\
\text { SILL (Oxford, 1990). }\end{array}$ & $\begin{array}{l}\text { 1. Out of six strategies, metacognitive } \\
\text { strategies were reported to be second most } \\
\text { frequently used strategies. } \\
\text { 2. Positive significant relationship between } \\
\text { strategy use and language learning beliefs. }\end{array}$ & \\
\hline $\begin{array}{l}\text { Purdie } \\
\text { and } \\
\text { Oliver } \\
\text { (1999) }\end{array}$ & $\begin{array}{l}\text { Language } \\
\text { learning } \\
\text { strategies used } \\
\text { by bilingual } \\
\text { school-aged } \\
\text { children }\end{array}$ & $\begin{array}{l}58 \text { bilingual school } \\
\text { children } \\
\text { Age: } 9 \text { to } 12 \\
\text { *Location: Australia }\end{array}$ & $\begin{array}{c}\text { *Mixed-methods } \\
\text { (Structured interviews } \\
\text { and questionnaires) } \\
\text { S.E measure: Language } \\
\text { efficacy questionnaire } \\
\text { (developed by } \\
\text { researcher) } \\
\text { Metacognitive } \\
\text { strategies measure: } \\
\text { Language learning } \\
\text { strategies questionnaire } \\
\text { (Oliver and McKay, } \\
\text { 1996). }\end{array}$ & $\begin{array}{l}\text { 1. Metacognitive strategies were used most } \\
\text { frequently. } \\
\text { 2. Cultural group, i.e. Asian, Arabic and } \\
\text { European didn't make any difference in } \\
\text { employing metacognitive strategies. } \\
\text { 3. Metacognitive strategies are significantly } \\
\text { and positively correlated to language efficacy } \\
\text { beliefs. }\end{array}$ & \\
\hline $\begin{array}{c}\text { Jee } \\
(2015)\end{array}$ & $\begin{array}{l}\text { Language } \\
\text { learners' strategy } \\
\text { use and self- } \\
\text { efficacy: Korean } \\
\text { heritage learners } \\
\text { versus non- } \\
\text { heritage learners. }\end{array}$ & $\begin{array}{c}92 \text { Korean as a } \\
\text { foreign language } \\
\text { (KFL) university } \\
\text { students (47M \& } 45 \\
\text { F) } \\
\text { *Age: } 18 \text { to } 35 \\
\text { (*Avg. age }=20.8) \\
\text { *Location: USA }\end{array}$ & $\begin{array}{c}\text { *QUAN } \\
\text { S.E measure: Self- } \\
\text { efficacy scale (Gahungu } \\
\text { 2010). } \\
\text { Metacognitive } \\
\text { strategies measure: } \\
\text { SILL (Oxford, 1990). }\end{array}$ & $\begin{array}{l}\text { 1. Non-heritage students employed } \\
\text { metacognitive strategies more frequently as } \\
\text { compared to heritage students. } \\
\text { 2. Level of self-efficacy of heritage students } \\
(\mathrm{M}=3.35) \text { was higher as compared to non- } \\
\text { heritage students }(\mathrm{M}=2.83) \text {. } \\
\text { 3. Regarding the correlations, there was } \\
\text { statistically significant positive relationship } \\
\text { between self-efficacy and strategy usage. }\end{array}$ & $\checkmark$ \\
\hline $\begin{array}{l}\text { McCrud } \\
\text { den, } \\
\text { Perkins } \\
\text { and } \\
\text { Putney } \\
(2005)\end{array}$ & $\begin{array}{l}\text { Self-efficacy and } \\
\text { interest in the use } \\
\text { of reading } \\
\text { strategies }\end{array}$ & $\begin{array}{c}234^{\text {th }} \text { grade students } \\
\text { (12M \& 11F) } \\
\text { *Location: USA }\end{array}$ & $\begin{array}{c}\text { *QUAN (pre/post-test } \\
\text { design) } \\
\text { S.E measure: Self- } \\
\text { efficacy scale } \\
\text { (developed by the } \\
\text { researcher) } \\
\text { Metacognitive } \\
\text { strategies measure: } \\
\text { Metacognitive reading } \\
\text { strategies were taught to } \\
\text { the students. }\end{array}$ & $\begin{array}{l}\text { Self- efficacy increased from pre-instruction } \\
(\mathrm{M}=18.87, \mathrm{SD}=2.03) \text { to post-instruction } \\
(\mathrm{M}=20.78, \mathrm{SD}=2.83) .\end{array}$ & \\
\hline $\begin{array}{c}\text { Yang } \\
\text { (1999) }\end{array}$ & $\begin{array}{l}\text { The relationship } \\
\text { between EFL } \\
\text { learners' beliefs } \\
\text { and learning } \\
\text { strategy use }\end{array}$ & $\begin{array}{c}\text { 505 EFL university } \\
\text { students }(311 \mathrm{~F} \& \\
194 \mathrm{M}) \\
\text { *Location: Taiwan }\end{array}$ & $\begin{array}{c}\text { *Mixed-methods } \\
\text { S.E measure: Beliefs } \\
\text { About Language } \\
\text { Learning Inventory } \\
\text { (BALLI) (Horwitz's, } \\
\text { 1987). } \\
\text { Metacognitive } \\
\text { strategies measure: } \\
\text { SILL (Oxford, 1990). }\end{array}$ & $\begin{array}{l}\text { 1. Level of English self-efficacy was high. } \\
\text { 2. Significant relationship between learner's } \\
\text { beliefs metacognitive strategies. }\end{array}$ & \\
\hline $\begin{array}{c}\text { Stracke } \\
(2016)\end{array}$ & $\begin{array}{l}\text { Language } \\
\text { learning } \\
\text { strategies of } \\
\text { Indonesian } \\
\text { primary school } \\
\text { students: In } \\
\text { relation to self- } \\
\text { efficacy beliefs }\end{array}$ & $\begin{array}{l}522 \text { grade } 6 \text { students } \\
(62 \% \mathrm{~F} \% 38 \% \mathrm{M}) \\
\text { *Avg. age: } 11 \text { years } \\
\text { *Location: Indonesia }\end{array}$ & $\begin{array}{c}\text { QUAN } \\
\text { S.E measure: The } \\
\text { Children's Self-efficacy } \\
\text { in Learning English } \\
\text { Questionnaire (C- } \\
\text { SELEQ) (Developed by } \\
\text { researcher). } \\
\text { Metacognitive } \\
\text { strategies measure: } \\
\text { The Indonesian }\end{array}$ & $\begin{array}{l}\text { 1. Metacognitive strategies were used most } \\
\text { frequently. } \\
\text { 2. High self-efficacious learners employed } \\
\text { more metacognitive strategies than low self- } \\
\text { efficacious students. } \\
\text { 3. Positive significant relationship between } \\
\text { self-efficacy and metacognitive strategies. }\end{array}$ & \\
\hline
\end{tabular}


M. Waleed Shehzad, Dr. Mohd Hilmi bin Hamzah, Dr. Rafizah Mohd Rawian

\begin{tabular}{|c|c|c|c|c|}
\hline & & & $\begin{array}{c}\text { Children's SILL } \\
\text { (Gunning's, 1997). }\end{array}$ & \\
\hline $\begin{array}{l}\text { Magogw } \\
\text { e and } \\
\text { Oliver } \\
(2007)\end{array}$ & $\begin{array}{l}\text { The relationship } \\
\text { between } \\
\text { language } \\
\text { learning } \\
\text { strategies, } \\
\text { proficiency, age } \\
\text { and self-efficacy } \\
\text { beliefs: A study } \\
\text { of language } \\
\text { learners in } \\
\text { Botswana. }\end{array}$ & $\begin{array}{l}480 \text { primary, } \\
\text { secondary and } \\
\text { tertiary level } \\
\text { students. } \\
\text { *Location: } \\
\text { Botswana. }\end{array}$ & $\begin{array}{c}\text { QUAN } \\
\text { S.E measure: The } \\
\text { Morgan-Jinks Student } \\
\text { Efficacy Scale (MJSES) } \\
\text { Jinks and Morgan } \\
\text { (1999). } \\
\text { Metacognitive } \\
\text { strategies measure: } \\
\text { SILL (Oxford. 1989). }\end{array}$ & $\begin{array}{l}\text { 1. Out of six strategies, metacognitive } \\
\text { strategies were employed most frequently by } \\
\text { secondary and tertiary level students. } \\
\text { However, primary level students rated them as } \\
\text { second most employed strategies. } \\
\text { 2. Those students who had high proficiency } \\
\text { level were high self-efficacious and vice versa. } \\
\text { 3. Positive significant relationship between } \\
\text { self-efficacy beliefs and language learning } \\
\text { strategies including metacognitive strategies. }\end{array}$ \\
\hline
\end{tabular}


Table 2: $\quad$ List of included and excluded studies along with the reasons for exclusion of some studies

\begin{tabular}{|c|c|c|c|c|c|}
\hline $\begin{array}{l}\text { Sr. } \\
\text { no. }\end{array}$ & Studies & Journal & Category & $\begin{array}{l}\text { Selected/Rejec } \\
\text { ted studies }\end{array}$ & $\begin{array}{l}\text { Reason of exclusion of } \\
\text { studies }\end{array}$ \\
\hline 1 & Zarei and Gilanian (2015) & $\begin{array}{l}\text { British Journal of Education, } \\
\text { Society \& Behavioural } \\
\text { Science }\end{array}$ & Refereed & $\checkmark$ & \\
\hline 2 & Tavakoli and Koosha (2016) & Porta Linguarum & Non-refereed & $x$ & Journal was non-refereed \\
\hline 3 & $\begin{array}{l}\text { Taghinezhad, Dehbozorgi and } \\
\text { Esmaili (2015) }\end{array}$ & $\begin{array}{l}\text { Modern Journal of } \\
\text { Language teaching Methods }\end{array}$ & Refereed & $\checkmark$ & \\
\hline 4 & Rahimi and Abedi (2014) & $\begin{array}{l}\text { Procedia-Social and } \\
\text { Behavioral Sciences }\end{array}$ & Refereed & $\checkmark$ & \\
\hline 5 & $\begin{array}{l}\text { Yailagh, Birgani, Boostani and } \\
\text { Hajiyakhchali (2013) }\end{array}$ & $\begin{array}{l}\text { Procedia-Social and } \\
\text { Behavioral Sciences }\end{array}$ & Refereed & $\checkmark$ & \\
\hline 6 & $\begin{array}{l}\text { Javanmard, Hoshmandja and } \\
\text { Ahmadzade (2012) }\end{array}$ & $\begin{array}{l}\text { Journal of Life Science and } \\
\text { Biomedicine }\end{array}$ & Refereed & $\checkmark$ & \\
\hline 7 & $\begin{array}{l}\text { Nosratinia, Saveiy and Zaker } \\
\text { (2014) }\end{array}$ & $\begin{array}{l}\text { Theory and Practice in } \\
\text { Language Studies }\end{array}$ & Refereed & $\checkmark$ & \\
\hline 8 & Kargar and Zamanian (2014) & $\begin{array}{l}\text { International Journal of } \\
\text { Language Learning and } \\
\text { Applied Linguistics World }\end{array}$ & Non-refereed & $x$ & Journal was non-refereed \\
\hline 9 & Naseri and Zaferanieh (2012) & World Journal of Education & Non-refereed & $x$ & Journal was non-refereed \\
\hline 10 & Zare and Mobarakeh (2011) & $\begin{array}{l}\text { Studies in Literature and } \\
\text { Language }\end{array}$ & Refereed & $\checkmark$ & \\
\hline 11 & Ahmadian and Pasand (2017) & The Reading Matrix & Refereed & $\checkmark$ & \\
\hline 12 & $\begin{array}{l}\text { Ghavamnia, Kassaian and } \\
\text { Dabaghi (2011) }\end{array}$ & $\begin{array}{l}\text { Journal of Language } \\
\text { Teaching and Research }\end{array}$ & Refereed & $\checkmark$ & \\
\hline 13 & $\begin{array}{l}\text { Bonyadi, Nikou and Shahbaz } \\
(2012)\end{array}$ & English language teaching & Refereed & $\checkmark$ & \\
\hline 14 & Uçar (2016) & Curr Res Educ & Non-refereed & $x$ & Journal was non-refereed \\
\hline 15 & Yilmaz (2010) & $\begin{array}{l}\text { Procedia-Social and } \\
\text { Behavioral Sciences }\end{array}$ & Refereed & $\checkmark$ & \\
\hline 16 & Keskin (2014) & $\begin{array}{l}\text { International Journal of } \\
\text { Social Sciences \& Education }\end{array}$ & Non-refereed & $x$ & Journal was non-refereed \\
\hline 17 & Sönmez and Durmaz (2017) & $\begin{array}{l}\text { Turkish Online Journal of } \\
\text { English Language Teaching }\end{array}$ & Non-refereed & $x$ & Journal was non-refereed \\
\hline 18 & Tuncer and Dogan (2016) & $\begin{array}{l}\text { International Journal of } \\
\text { Learning and Development }\end{array}$ & Non-refereed & $x$ & Journal was non-refereed \\
\hline 19 & Yang and Wang (2015) & Taiwan Journal of TESOL & Non-refereed & $x$ & Journal was non-refereed \\
\hline 20 & Shang (2010) & Asian EFL Journal & Refereed & $\checkmark$ & \\
\hline 21 & Yang (1999) & System & Refereed & $\checkmark$ & \\
\hline 22 & Jee (2015) & Language Research & Refereed & $\checkmark$ & \\
\hline 23 & $\begin{array}{l}\text { McCrudden, Perkins \& Putney } \\
(2005)\end{array}$ & $\begin{array}{l}\text { Journal of Research in } \\
\text { Childhood Education }\end{array}$ & Refereed & $\checkmark$ & \\
\hline 24 & Wong (2005) & RELC Journal & Non-refereed & $x$ & Journal was non-refereed \\
\hline 25 & Mokhtar (2015) & $\begin{array}{l}\text { PEOPLE: International } \\
\text { Journal of Social Sciences }\end{array}$ & Non-refereed & $x$ & Journal was non-refereed \\
\hline 26 & Li \& Wang (2010) & Asian EFL Journal & Refereed & $\checkmark$ & \\
\hline 27 & Stracke (2016) & System & Refereed & $\checkmark$ & \\
\hline 28 & Magogwe and Oliver (2007) & System & Refereed & $\checkmark$ & \\
\hline 29 & $\begin{array}{l}\text { Cera, Mancini and Antoniette } \\
(2013)\end{array}$ & $\begin{array}{l}\text { Journal of Educational, } \\
\text { Cultural and Psychological } \\
\text { Studies }\end{array}$ & Refereed & $\checkmark$ & \\
\hline 30 & Kassem (2015) & English Language Teaching & Refereed & $\checkmark$ & \\
\hline 31 & Purdie and Oliver (1999) & System & Refereed & $\checkmark$ & \\
\hline
\end{tabular}

